tion. Second, the cracks post-date the deposition of the sand, but antedate its lithifcation to form a firm sandstone and the unconsolidated sand subsided and flowed down into and filled the fissures.

By this process of elimination we are forced to the consideration of the view that the fissures were formed after the granite had been covered by the sedimentary deposits and before their complete consolidation, the unconsolidated portions naturally contributing to the filling of the fissures and the formation of the dikes. There are two questions especially which the acceptance of this explanation would require to be answered in the affirmative. First, are there, among the sediments of the Manitou and Manitou Park basins, any that, aside from structural features like stratification, which would, of course, be obliterated during the filling of the fissures, present a reasonably close agreement in character (composition and texture) with the sandstone of the dikes? Second, may we reasonably assume that these sediments were, in part at least, unconsolidated or imperfectly consolidated at the time when the fissures were formed ? The only sandstone formations that need be considered in this connection are the Potsdam, Carbon iferous, Triassic and Dakota. Of these four sandstone horizons the last three bear no special resemblance to the material of the sandstone dikes. On the other hand, I became convinced before the field work was finished that the Potsdam beds and the dikes are lithologically identical. The dike rock is absolutely indifferent to the changes in the character of the neighboring formations, showing no appreciable variation, as in succession, from Manitou southeast to Cheyenne Cañon, the Potsdam, Silurian, Carboniferous, Triassic and Dakota beds abut against or border the great fault.

The close association of the dikes, throughout the entire belt, with the great displacement, and their unvarying lithological similarity to the Potsdam sandstone, have suggested to me that the dikes probably date from the formation of the Ute fault; that the fault probably dates from the time when the Potsdam beds, which are still, at the base, in part of a more or less friable character, were imperfectly consolidated and covered the entire region; that the fault, as is likely to be the case with a great displacement, was not simple, but that a moderate breadth of the granite and overlying formations was traversed by a series of parallel fissures; and that the dikes resulted from the sinking of the Potsdam sandstone and sand into the fault fissures. Such local subsidences of the friable sandstone would naturally be attended by a more or less complete obliteration of the bedding.

No single feature of the dikes is more significant than the great breadth of individual examples. Although presenting, apparently, an insuperable obstacle to all the other suggested explanations of the sandstone dikes, it offers no difficulty whatever to the theory proposed here, for we have only to make the extremely probable supposition that sheets of granite of varying width and bordered by complementary faults have settled down relatively to the bordering masses, bearing with them their loads of Potsdam sediment.

W. O. Crosby.

\section{EXHIBITION IN SCIENCE BY THE NEW YORK ACADEMY OF SCIENCES.}

The Fourth Annual Exhibition of Recent Progress in Science, given by the New York Academy of Sciences, was held at the American Museum of Natural History on April 5 th and 6th, and was in every way the most successful in the history of the Society. The exhibit occupied the floor space of the main hall and bird gallery, and was attended by an estimated number of more 
than three thousand people. The first evening was devoted to a reception to the members of the Academy and a few invited guests, and was more or less social in its nature. On the afternoon of the second day the visitors included many from the public and private schools of city who were especially invited. On the second evening the reception was to members of the Scientific Alliance and other friends, and the occasion was more informal and public than on the previous evening.

Besides the Exhibition, the committee had planned a program of considerable interest, for the second evening, including a short informal talk by Dr. Nicola Tesla on 'The Streams of Lenard and Röntgen.' Dr. Tesla gave a short synopsis of some of his more recent discoveries and exhibited several pieces of apparatus for producing high power, electrical currents with simple machines. This talk was preceded by a short review of the scientific results of the year by Professor J.J. Stevenson, President of the Academy, and an address of welcome by Mr. Morris K. Jesup, President of the Musenm, to whose courtesy and hospitality much of the success of the occasion was due.

In every way the success of the Exhibition was very great and very encouraging to workers in science, for the manifest interest of the large numbers of people attending was a striking sign of the times. Interest, and not popular curiosity, attracted the greater number of visitors. The attention that the Exhibition was given both by people of New York and the newspapers showed that this annual feature of the Academy is fast becoming one of the occasions of the year to which many people look forward with very great anticipation.

The reception was in charge of a committee of Professor Henry F. Osborn, Mr. Charles F. Cox and Professor Richard E. Dodge. They were assisted in the plan- ning of the details and in the execution thereof by a committee of one from each department represented, of which a list follows : Anatomy, Professor George S. Huntington; Astronomy, Professor J. K. Rees; Botany, Professor L. M. Underwood; Chemistry, Professor Chas. A. Doremus; Electricity, Mr. George F. Sever; Ethnology and Archæology, Mr. Franz Boas and Mr. M. H. Saville ; Experimental Psychology, Professor J. McK. Cattell ; Geology, Professor J. F. Kemp ; Mineralogy, Mr. George F. Kunz; Paleontology, Mr. Gilbert van Ingen; Photography, Professor William Stratford; Physics, Professor William Hallock and Professor J. F. Woodhull; Physiography, Professor R. E. Dodge; Zoölogy, Professor C. L. Bristol and Mr. Bashford Dean.

The exhibits that received the most attention were naturally those concerning which there has been the most said publicly within the last year. The electric furnaces, including the one used by Dr. Henri Moissan in his lectures before the Academy ; the outfits for illustrating the uses and effects of the Röntgen rays, and the instruments of fatigue in experimental psychology were continually surrounded by a large number of interested listeners and spectators.

Inasmuch as the Exhibition was arranged to show progress during the last year only, there were few duplications of former exhibits in any department. Everything shown was in a way new and received attention in proportion to its importance. The chairmen of the departments were in attendance during most of the time and gladly answered questions and explained particular points of interest. In this way the visitors felt that they were guests rather than sightseers. Nothing of an advertising character was allowed, and hence the air of the whole Exhibition was serious and truly scientific.

Besides the exhibits that were mentioned 
above as being the most attentively studied, there were many other exhibits worthy of mention, of which only a few can be spoken of here. In chemistry, besides the exhibits noted, the most interesting materials were the artistic glasses exhibited by the Tiffany Decorative Company, and several striking pieces of apparatus exhibited by the chairman.

In electricity the enclosed arc lamps, the Crookes tubes and fluoroscopes received a great deal of attention. In ethnology and archæology the busts of the Kwakiutl Indians and the paintings, diagrams and specimens illustrating the culture of the primitive American races were the more notable exhibits.

In geology the exhibit of clays from various parts of America and the products made therefrom won a great deal of well deserved attention. The photographs from the Cornell Greenland expedition illustrating some of the conclusions of Professor Tarr regarding the effects of glaciers in Greenland were of interest both to the unscientific and the scientific. The associated subject mineralogy had on exhibition a large series of new and valuable specimens which cannot be noted here in detail. In paleontology was one of the largest exhibits that took the greatest amount of labor in arranging. The exhibit included fossils from some of the more important localities illustrating the work accomplished by leading paleontologists of the East. Besides the stratigraphic collections exhibited, there was a large series of fossil insects from Florissant, Colorado, including some very handsome butterflies exhibited by Mr. S. H. Scudder. The preparations of Beecher, of Yale University, illustrating the structures of Trilobites, were much studied, representing, as they do, the best knowledge of what has been until recently butlittle known. The fossil gums including insects of all kinds also deserve a note. In vertebrate paleon- tology there was a large collection of fos: sils from the American Museum, and some striking water colors of the reproductions of extinct mammalia.

The exhibit in photography included some very beautiful prints and some of the more recent apparatus, and received much attention. It was, however, disappointing to those in charge because so many exhibitors failed to send promised materials, some of which were of especial interest and value.

In physiography the exhibit included several large models of New England and New York, representing the newest and best work of Mr. Howell, of Washington. A series of teaching models from Professor W. M. Davis, which have just been cast, also were exhibited uncolored. These models represent the best work of the year outside of the numerous publications.

In zoology the most important exhibition was the collection of animals from the Puget Sound region, exhibited by Columbia University. Many of the forms represented were shown in all stages from embryonic to adult and are very valuable additions to our knowledge of the lower animals. The plans and models of the new Zoological Park of New York City also were shown in some detail and naturally received very much attention.

The Exhibition represents a large investment of time and labor on the part of the few in charge, and should bring very valuable results to the Academy in many ways. It has aroused considerable interest in many places at a distance from the city, and it is hoped that the plan of having such exhibitions may be followed by other scientific societies in the country. If scientists would have the support of the public they must show their work. There is no better way to show work than by a scientific exhibition in which the popular and wonderful are exhibited together with the more valuable and enduring. The committee in 
charge feel that the investment of time, money and labor has paid for itself, for the interest we have aroused has been an inspiration to all of us and, we think, to many others. It has shown that science has a very strong hold upon the public and that the public appreciate the work of abstruse science, whether or not it shows immediate results from an economic standpoint.

Richard E. Dodge.

\section{THE MISSOURI BOTANICAL GARDEN.*}

DURING the year 1896 the ornamental features of the Garden were of the same general character as heretofore, and about the same number of species and nearly the same of individuals were cultivated for this purpose, in the open air, as in 1895. The house collections, on the other hand, especially that of orchids, have been considerably increased, both in size and variety. A conservative estimate by the Head Gardener shows that at present about two and onehalf times as many species and named varieties of plants are cultivated as in 1889 . At the end of 1895 an inventory of the plants in cultivation at the Garden showed that 3921 species and varieties other than annuals were cultivated at that time. During the past year, while considerable additions have been made, it is probable that certain species have dropped out of cultivation, so that in the absence of a special inventory it is possible to state merely that the number now in cultivation is unquestionably somewhat greater than that in 1895.

It is estimated that, for various temporary reasons, the number of visitors to the Garden during 1896 was scarcely as large as in the preceding year. On the open Sunday afternoon in June 10,598 persons passed the gate, and on the corresponding Sunday afternoon in September 13,589 visitors were

*From advance sheets of the eighth annual report of the Director, Professor Wm. Trelease. counted. So far as estimates can be made from the data at hand, the number of visitors to the Garden is now about one-half greater than in 1889 , though, as no automatic register of visitors is kept at the gate, the estimates are not accurate.

As a result of the most destructive hailstorm that has ever been experienced at the Garden, some 6,000 lights of glass were broken on tne 21st of May last, the falling glass doing incalculable damage to many of the plants, which were further exposed to the weather for a considerable time. Cacti and other plants which are sheltered under glass during the winter, but which had been placed in the rockeries and elsewhere before the storm, were either destroyed or so badly bruised that it is impossible even yet to count the final loss. Some idea of the force of the falling hail may be obtained from the statement that the ribbed glass on the roof of the Linnæan house, nearly a quarter of an inch thick, was in considerable part broken.

Closely following this storm, the tornado of May 27th, which caused great loss of life and property in and about St. Louis, devastated a considerable portion of the Garden. While the grounds, fortunately, were not actually traversed by the cyclonic funnel, but were exposed only to the strong northwest gale which accompanied it, the violence of the wind was such that a number of the structures on the grounds were either unroofed or totally wrecked, while some 450 trees, many of them of large size, were totally or practically destroyed, and a large percentage of those left standing were seriously broken. A more graphic view of the destruction of trees may be obtained from the statement that 186 cords of firewood have been prepared from the more workable trunks and larger branches of the trees removed. Aside from the direct injury, it is probable that no small number of those left have suffered from unwonted ex- 